\title{
Determination of antioxidant and antimicrobial activities of the extracts of aerial parts of Portulaca quadrifida
}

\author{
Zelalem Yibralign Desta ${ }^{*}$ and Desie Alemaw Cherie $^{2}$
}

\begin{abstract}
Background: The extracts from the aerial parts of Portulaca quadrifida have been reported to show the total flavonoid content, antioxidant and antibacterial activities.

Results: Our results revealed that the total flavonoid content of methanol and chloroform extracts is $2.335 \pm 0.0097$ and $1.7312 \pm 0.0082 \mathrm{mgQE} / 100 \mathrm{~g}$ respectively. The two extracts also showed good antioxidant activity and total phenolic content as well as weak to moderate antibacterial activity against some bacteria.

Conclusions: The extracts the aerial parts of the P. quadrifida showed good total flavonoid content, DPPH radical scavenging activity and antibacterial activity. In addition to this, the extracts also showed the presence of some important compounds by phytochemical analysis.
\end{abstract}

Keywords: Portulaca quadrifida, Total flavonoid content, Antioxidant activity, Total phenolic content and antibacterial activities

\section{Background}

Portulaca quadrifida, commonly known as "chicken weed", a herb belongs to the Portulacaceae family, is endemic to Ethiopia, in most dry area of Benshangul Gumuz, konso, Ethio-Somalia, Oromia, Kaffa and Hararghe regions. Portulaca quadrifida (known as "Kimma" in Amharic and Kawa in shinasha) is a prostrate, matforming annual or short-lived perennial herb with much branched, spreading, articulated, fleshy stems up to $50 \mathrm{~cm}$ long or longer, rooting freely from the nodes, often flushed reddish; nodes with a dense whorl of whitish hairs [1]. In Ethiopian traditional medicine, the aerial parts of Portulaca quadrifida used as food and used for the treatment of several diseases including gastric ulcer, ophthalmia, as an anti-microbial, anti-hyperglycemic, and for its antioxidant properties used in preventing different kinds of sickness and disorders [2]. Several studies suggested that Portulaca quadrifida is a good natural

\footnotetext{
${ }^{*}$ Correspondence: yibrazelalem@yahoo.com

${ }^{1}$ Department of Chemistry, College of Science, Bahir Dar University, P. O.

Box 79, Bahir Dar, Ethiopia

Full list of author information is available at the end of the article
}

antioxidant that can be used as health promoting agent for various disorders including diabetes mellitus and other kinds of diseases [3]. Herein we reported the total flavonoid content, antioxidant activity and antibacterial activities of the extracts of the aerial parts of Portulaca quadrifida.

\section{Results and discussion \\ Determinations of total phonolic content}

The total phenolic content (TPC) of the extracts of the aerial parts of $P$. quadrifida was determined in terms of Gallic Acid equivalents per $100 \mathrm{~g}$ of dry weight of the sample (mgGA/100 g) as shown in Table 1 . According to the study, it was evident that methanol extract had the highest level of phenolic content $(4.9029 \pm 0.0087 \mathrm{mgGAE} / 100 \mathrm{~g})$ while petroleum ether extract of $P$. quadrifida was the least $(2.4914 \pm 0.0028$ mgGAE/100 g). The maximum total phenolic content was recorded in more polar solvent extract whereas the minimum total phenolic content was recorded in non-polar solvent extract. These results suggested that the extraction of phenolic compounds is influenced by the polarity of the solvent used. In other ways, the 
Table 1 Total phenolic content of $P$. quadrifida extracts

\begin{tabular}{ll}
\hline Different extracts & $\begin{array}{l}\text { TPC } \\
\text { in } \text { mgGAE/g } \\
\text { dry extracts }\end{array}$ \\
\hline Methanol extract & $4.9029 \pm 0.0087$ \\
Chloroform extract & $4.5957 \pm 0.0055$ \\
Petroleum ether extract & $2.4914 \pm 0.0028$ \\
\hline
\end{tabular}

Values are expressed as mean \pm SD of triplicate analysis

reaction of $\mathrm{Mo}^{6+}$ (yellow), from Folin-Ciocalteu reagent, is changed to less oxidation state $\left(\mathrm{Mo}^{+4}, \mathrm{Mo}^{+5}\right)$ (blue color) depend on the polarity of the solvent and the intensity of color indicates the concentration of phenolic content in the sample. Basically, methanol extract of P. quadrifida has better intense blue color, as compared to petroleum ether extract, which has very less color intensity. The total phenolic content result might vary by the maturity of the plant. The total phenolic content at the mature growth stage was lower than in the plants at the developing stage meaning levels of polyphenolic compounds decreased rapidly with age due to their dilution with leaf growth [4].

\section{Determination of total flavonoid content}

The total flavonoid content of the extracts of the aerial parts of $P$. quadrifida was evaluated and the results are shown in Table 2. The highest total flavonoid content of $P$. quadrifida extract was recorded in methanol extract $(2.335 \pm 0.0097)$ however the least total flavonoid content was recorded with petroleum ether extract $(1.357 \pm 0.0035)$. According to this study, the highest amount of the total flavonoid content was recorded in polar solvent extract and decreases with decreasing the polarity of the solvent in the same order as total phenolic content shown above.

\section{Determination of antioxidant capacity}

The antioxidant activity of the extracts of the aerial parts of $P$. quadrifida was evaluated by using DPPH radical scavenging assay as shown in Table 3. The scavenging effect of different extracts of $P$. quadrifida on the DPPH radical decreases in the order of methanol extract, chloroform

\begin{tabular}{lr}
$\begin{array}{l}\text { Table } 2 \text { Total flavonoid content of the extracts of } \boldsymbol{P} . \\
\text { quadrifida }\end{array}$ \\
\hline Different extracts & $\begin{array}{c}\text { TFC in } \mathbf{m g Q E} / \mathbf{g} \\
\text { dray extracts }\end{array}$ \\
\hline Methanol extract & $2.335 \pm 0.0097$ \\
Chloroform extract & $1.7312 \pm 0.0082$ \\
Petroleum ether extract & $1.357 \pm 0.0035$
\end{tabular}

Values are mean of \pm SD triplicate analysis extract and petroleum ether extract. The highest percentage inhibition for methanol extract compared to two other solvents could be due to high polarity nature of solvent and highly polar miscible compounds found in the plant. As the concentration of phenolic compound increases, degree of hydroxylation of the phenolic compound also increases which resulted to increase the scavenging activity (\% inhibition). The increase in DPPH scavenging activity directly related to antioxidant capacity of the $P$. quadrifida extracts. As a result methanolic extract of P. quadrifida which has highest DPPH radical scavenging activity showed fairly highest antioxidant activity in comparison to other extracts. The presence of phenolic acid in the extract of tested plant increases the probability of reaction with free radical, which lead to decrease the amount of free radical. In this study antioxidant assay of DPPH radical scavenging capacity (\%), total phenolic, and total flavonoid contents were used to evaluate the antioxidant activity of $P$. quadrifida extracts. A good correlation between DPPH radical scavenging activity with TPC $\left(\mathrm{R}^{2}=\right.$ 0.782) was observed and furthermore, a reasonable correlation between DPPH and TFC $\left(\mathrm{R}^{2}=0.996\right)$ was observed. Results obtained from the experimental data showed that there was good correlation between total flavonoid and antioxidant activity of different extracts of $P$. quadrifida with correlation coefficient $\left(R^{2}\right) 0.996$.

\section{Determination of antimicrobial activity of $P$. quadrifida}

Different extracts from the aerial parts of $P$. quadrifida demonstrated antibacterial activities against both Grampositive and Gram-negative bacteria strains. In this study $250 \mathrm{mg} / \mathrm{L}$ and $200 \mathrm{mg} / \mathrm{L}$ of methanol extract of Portulaca quadrifida recorded the most significant antimicrobial activity against all tested bacteria but chloroform extract showed good activity against fungi. Though methanol extract showed broad spectrum of activity against all tested bacteria, especially $S$. aurues and E. coli are the most susceptible pathogens. In addition, the methanol extracts of Portulaca quadrifida also showed significant antibacterial activity against Gram negative bacteria (Escherichia coli and Klebsiella pneumoniae) and Gram positive bacteria (Staphylococcus pyogenes and Staphylococcus aureus), respectively. However, petroleum ether extract showed least activity against all bacterial organisms. The significant and higher antibacterial activity might be due to the presence of flavonoids in the plant as described by Mutyala and Kishore [5]. $0.3 \%$ w/v of Gentamycine drug reference and DMSO were used as a positive and negative control respectively. Gentamycine showed 27, 17, 29 and $19 \mathrm{~mm}$ zone of inhibition on $E$. coli, K. pneumoniae, S. aureus and S. pyogenes respectively while DMSO had no sensitivity on those four bacterial species. 
Table 3 DPPH radical scavenging activity of $P$. quadrifida extracts at different concentrations

\begin{tabular}{|c|c|c|c|c|}
\hline \multirow[t]{2}{*}{ S. no } & \multirow{2}{*}{$\begin{array}{l}\text { Concentration of extract (mg } \\
\text { /L) }\end{array}$} & \multicolumn{3}{|c|}{ \%DPPH scavenging activity } \\
\hline & & Methanol & Chloroform & Petroleum ether \\
\hline 1 & $20(w / v)$ & $25.3541 \pm 0.0272$ & $23.1373 \pm 0.00804$ & $22.8602 \pm 0.0020$ \\
\hline 2 & $40(w / v)$ & $30.9421 \pm 0.0038$ & $29.4874 \pm 0.0100$ & $26.4547 \pm 0.0188$ \\
\hline 3 & $60(w / v)$ & $36.8042 \pm 0.0056$ & $34.1595 \pm 0.0054$ & $30.8344 \pm 0.0047$ \\
\hline 4 & $80(w / v)$ & $38.2620 \pm 0.0003$ & $37.3599 \pm 0.0062$ & $33.0511 \pm 0.0039$ \\
\hline 5 & $100(w / v)$ & $46.7595 \pm 0.0069$ & $42.4030 \pm 0.0053$ & $44.5428 \pm 0.0174$ \\
\hline
\end{tabular}

\section{Determination of anti-fungal activity of the extracts of $P$. quadrifida}

In this study the drug reference which was used for antifungal test was Gentamicine $(0.3 \% \mathrm{w} / \mathrm{v})$ as a positive control and DMSO as a negative control. Gentamycine has 23 and $18 \mathrm{~mm}$ zone of inhibition on yeast and mold respectively but DMSO has no activity on the above two fungal species. As shown in Tables 4 and 5, each different extracts of the aerial parts of $P$. quadrifida showed a good inhibition zone against each bacterium and fungus species at $250 \mathrm{mg} / \mathrm{mL}$ and $200 \mathrm{mg} / \mathrm{mL}$ of extract. The antifungal activity of chloroform extract of $P$. quadrifida dominates over methanol and petroleum ether extracts towards the tested pathogens. It indicates, either the microbes might be relatively resistant to compound of the plant which is extracted by methanol and petroleum ether. The result of this study has shown that all the isolated bacteria were susceptible to all solvent extract of $P$. quadrifida in agar well diffusion assay. Thus $P$. quadrifida extracts will provide good ways to control microbial infection especially caused by those multidrugresistant pathogens. Although the most different extracts of $P$. quadrifida showed lower activities compared to the controlled used during the study. It has promising result that the plant has antimicrobial substance with an optimum potential to inhibit growth of tested pathogens in

Table 4 Antibacterial sensitivity of Portulaca quadrifida extracts

\begin{tabular}{|c|c|c|c|c|}
\hline \multirow[t]{2}{*}{ Test bacteria } & \multirow[t]{2}{*}{ Concentration in $(\mathrm{mg} / \mathrm{L})$} & \multicolumn{3}{|c|}{ Mean zone of inhibition $\pm \mathrm{SD}(\mathrm{mm})$} \\
\hline & & Petroleum ether & Chloroform & Methanol \\
\hline \multirow[t]{5}{*}{ Escherchia coli } & 250 & $7.1 \pm 1.6$ & $8.0 \pm 2.0$ & $11.88 \pm 1.0$ \\
\hline & 200 & $5.3 \pm 1.3$ & $4.0 \pm 0.7$ & $9.7 \pm 0.8$ \\
\hline & 150 & $1.2 \pm 0.8$ & $1.8 \pm 2.6$ & $6.4 \pm 1.3$ \\
\hline & 100 & Growth & Growth & $3.8 \pm 1.7$ \\
\hline & 50 & Growth & Growth & Growth \\
\hline \multirow[t]{5}{*}{ Klebsiella pneumoniae } & 250 & $5.3 \pm 1.1$ & $5.78 \pm 0.5$ & $10.3 \pm 1.3$ \\
\hline & 200 & $2.5 \pm 0.6$ & $3.1 \pm 2.1$ & $5.2 \pm 0.6$ \\
\hline & 150 & Growth & Growth & $1.5 \pm 1.4$ \\
\hline & 100 & Growth & Growth & Growth \\
\hline & 50 & Growth & Growth & Growth \\
\hline \multirow[t]{5}{*}{ Staphylococcus aureus } & 250 & $10.3 \pm 2.2$ & $10.7 \pm 3.0$ & $17.3 \pm 2.0$ \\
\hline & 200 & $6.2 \pm 2.1$ & $6.8 \pm 2.5$ & $10.2 \pm 1.75$ \\
\hline & 150 & $1.2 \pm 1.0$ & $1.5 \pm 0.7$ & $5.3 \pm 0.6$ \\
\hline & 100 & Growth & $1.2 \pm 0.5$ & $2.35 \pm 0.5$ \\
\hline & 50 & Growth & Growth & Growth \\
\hline \multirow[t]{5}{*}{ Streptococcus pyogenes } & 250 & $8.7 \pm 1.7$ & $9.3 \pm 2.1$ & $10.8 \pm 2.5$ \\
\hline & 200 & $5.0 \pm 1.3$ & $6.8 \pm 1.2$ & $7.3 \pm 1.8$ \\
\hline & 150 & $2.9 \pm 1.8$ & $1.4 \pm 2.3$ & $3.0 \pm 2.5$ \\
\hline & 100 & Growth & Growth & Growth \\
\hline & 50 & Growth & Growth & Growth \\
\hline
\end{tabular}

Values are expressed in mean \pm SD of three individual experiments

The word "growth" represents zero inhibition zone the extract at a given concentration 
Table 5 Inhibition zone of $P$. quadrifida extracts against standard fungus

\begin{tabular}{|c|c|c|c|c|}
\hline \multirow[t]{2}{*}{ Test fungi } & \multirow{2}{*}{$\begin{array}{l}\text { Concentration } \\
\text { in }(\mathrm{mg} / \mathrm{L})\end{array}$} & \multicolumn{3}{|c|}{ Mean zone of inhibition $\pm \mathrm{SD}(\mathrm{mm})$} \\
\hline & & $\begin{array}{l}\text { Petroleum } \\
\text { ether }\end{array}$ & Chloroform & Methanol \\
\hline \multirow[t]{5}{*}{ Yeast } & 250 & $8.4 \pm 0.6$ & $11.8 \pm 1.6$ & $10.2 \pm 2.1$ \\
\hline & 200 & $4.3 \pm 0.7$ & $6.0 \pm 2.2$ & $7.2 \pm 2.0$ \\
\hline & 150 & Growth & $2.4 \pm 2.5$ & $3.0 \pm 1.3$ \\
\hline & 100 & Growth & Growth & $1.2 \pm 1.0$ \\
\hline & 50 & Growth & Growth & Growth \\
\hline \multirow[t]{5}{*}{ Mold } & 250 & $12.5 \pm 2.1$ & $15.2 \pm 1.5$ & $10.5 \pm 1.6$ \\
\hline & 200 & $8.3 \pm 1.3$ & $7.7 \pm 1.7$ & $9.7 \pm 1.5$ \\
\hline & 150 & $3.3 \pm 0.8$ & $3.0 \pm 0.7$ & $4.3 \pm 2.1$ \\
\hline & 100 & Growth & $1.2 \pm 1.7$ & Growth \\
\hline & 50 & Growth & Growth & Growth \\
\hline
\end{tabular}

Values are expressed in mean $\pm S D$ of 3 individual experiments

The word "growth" represents zero inhibition zone the extract at a given concentration

advance over clinically used antibiotics compared with cost and side effect.

\section{Estimation of acute toxicity}

As shown in Table 6 below, aerial parts of P. quadrifida extracts were tested on laboratory animals under 14 days of observation period. None of the animals were showed any negative sign, depression, and symptom during observation period as compared with control animals. The result was showed a positive correlation between control and experimental animals regarding to the weight and other physical features of animals. Principally, the assumptions of Mutyala and Kishore [5] and Burkill [6] are not agreed with the outcomes of the present study.

\section{Experimental}

\section{Plant materials}

The fresh aerial parts of Portulaca quadrifida were collected in September 2017 from Benishangul Gumuz Regional State, Bullen district, Western Ethiopia, which is $310 \mathrm{~km}$ away from Bahir Dar and $680 \mathrm{~km}$ from Addis
Ababa. The plant species was identified and authenticated by Dr Ali Seid at Biology department, Bahir Dar University.

\section{Chemicals and reagents}

The analytical grade chemicals and reagents used for this study were petroleum ether (Blulux, india), chloroform (Lobachemie, India), methanol (Lobachemie, India), dimethyl sulphoxide (DMSO), potassium iodide (Lobachemie, India), Wagner's reagent (Iodine in potassium iodide), aluminum chloride (Blulux, India), iodine (Blulux, India), sodium nitrite, hydrochloric acid (LOBAChemie, India), sulfuric acid (Lobachemie, India), sodium hydroxide (Mumbai-400002, India), nitric acid, sodium carbonate, disodium hydrophosphate (Blulux, India), phosphoric acid (Blulux, India), sodium molybdate, sodium tungstate, iron chloride (Alpha Chemica, India), bromine, ascorbic acid (Blulux, INDIA-121005), Gallic acid, DPPH (himedia, India), quercitine (Alpha chemika, India), lithium sulphate, Muller Hinton agar and ammonia solution. All chemicals used for laboratory analysis were analytical grade that is greater than $97 \%$ in purity.

\section{Extraction and isolation}

The air-dried and ground aerial parts of $P$. quadrifida $(200 \mathrm{~g})$ were extracted by soaking successively in petroleum ether, chloroform $\left(\mathrm{CHCl}_{3}\right)$ and methanol $(\mathrm{MeOH})$ each for $48 \mathrm{~h}$ (two times with each solvent) and removal of the solvent under reduced pressure using a BUCHI flash evaporator to afford extracts of $2.70 \mathrm{~g}$ (for petroleum ether), $7.30 \mathrm{~g}$ (for chloroform) and $8.26 \mathrm{~g}$ (for $\mathrm{MeOH})$.

\section{Determination of total phenolic content (TPC)}

Total phenolic content of the aerial parts of P. quadrifida extracts was determined according to the Folin-ciocalteu method as described before by different researchers $[7,8]$. Each extract was dissolved in methanol $(100 \mathrm{~g} / \mathrm{L})$ and $1 \mathrm{~mL}$ of extract, $5 \mathrm{~mL}$ of Folin-Ciocalteu reagent

Table 6 Experimental weight of animals that were recorded within fixed time interval

\begin{tabular}{|c|c|c|c|c|c|}
\hline Day & Animal weight (g) & Mice 1 in gram & Mice 2 in gram & Mice 3 in gram & Mice 4 in gram \\
\hline \multirow[t]{2}{*}{ Day 1} & Test animal & 35.500 & 37.420 & 38.140 & 39.180 \\
\hline & Control animal & 35.160 & 35.860 & 37.450 & 39.380 \\
\hline \multirow[t]{2}{*}{ Day 7} & Test animal & 37.640 & 39.500 & 40.240 & 41.850 \\
\hline & Control animal & 37.880 & 36.510 & 37.940 & 41.500 \\
\hline \multirow[t]{2}{*}{ Day 14} & Test animal & 39.240 & 41.180 & 43.500 & 43.880 \\
\hline & Control animal & 39.000 & 39.250 & 40.450 & 43.850 \\
\hline
\end{tabular}


(diluted tenfold) and $4 \mathrm{~mL}(75 \mathrm{~g} / \mathrm{L})$ of sodium carbonate $\left(\mathrm{Na}_{2} \mathrm{CO}_{3}\right)$ solution were added together. After the reagents mixed with the extracts, the flasks were filled with distilled water up to the mark and the mixtures left for $30 \mathrm{~min}$ in dark area and absorbances were measured at $765 \mathrm{~nm}$.

\section{Determination of the total flavonoid content (TFC)}

The total flavonoid content of $P$. quadrifida crude extracts were determined by aluminum chloride assay as described before by different researchers $[9,10] .0 .25 \mathrm{~mL}$ of the extract was mixed with $1.25 \mathrm{~mL}$ of distilled water in $50 \mathrm{~mL}$ volumetric flask, followed by an immediate addition of $0.075 \mathrm{~mL}$ of $5 \% \mathrm{NaNO}_{2}$ and $5 \mathrm{~min}$ later, $0.15 \mathrm{~mL}$ of $10 \% \mathrm{AlCl}_{3}$ solution was added. After $6 \mathrm{~min} 0.5 \mathrm{~mL}$ of $1 \mathrm{M} \mathrm{NaOH}$ solution was added followed by $0.275 \mathrm{~mL}$ of distilled water and immediately the absorption at $510 \mathrm{~nm}$ was recorded by using UV-Vis spectrophotometer.

\section{Free radical scavenging activity}

Free radical scavenging activity of the extracts was determined by using the DPPH assay. DPPH assay is popular in natural product antioxidant studies and the antioxidant activity of $P$. quadrifida extracts was also evaluated on the bases of the radical scavenging effect of the stable 2,2-diphenyl-1-picrylhydrazyl (DPPH) by using those methods described previously by different researchers [11]. The methanol, chloroform, and petroleum ether extracts of $P$. quadrifida with different concentrations $(20 \%, 40 \%, 60 \%, 80 \%$ and $100 \%(\mathrm{v} / \mathrm{v}))$ were prepared by methanol to determine DPPH scavenging activity. An aliquot of $2 \mathrm{~mL}$ of $0.004 \%$ of DPPH solution was mixed with $1 \mathrm{~mL}$ of each extracts and the solutions were kept in dark for $30 \mathrm{~min}$ and the absorbance of the combination was measured at $517 \mathrm{~nm}$ using $\mathrm{UV}-\mathrm{Vis}$ spectrophotometer.

\section{Antimicrobial activity test}

Antimicrobial activities of the plant extracts P. quadrifida were done in microbiology laboratory, department of Biology at Bahir Dar University by using agar well diffusion method. Muller Hinton agar media was prepared for culturing selected Gram negative and positive bacteria by using standard methods. Four bacteria were selected, two Gram positive (S. aureus and S. pyogenes) and two Gram negative (E. coli, and K. pneumoniae). A series of plant extracts with concentrations $(50,100,150,200$ and $250 \mathrm{mg} / \mathrm{L}$ ) and standard antibiotics (Gentamycin) were added to the incubated plate by using filter paper. Then it was incubated for $24 \mathrm{~h}$ at $37^{\circ} \mathrm{C}$ and the experiment was repeated thrice, and the average values of zone of inhibition was recorded in $\mathrm{mm}$ for antimicrobial activity [12-14].

\section{Estimation of cytotoxicity}

The toxicity of the plant was done at Ethiopian food, medicine and health care administration and control authority. Experiments were performed using healthy young adult mice, non-pregnant and weighing 35-40 g. The experimental animals were divided into control and test groups containing four animals each. The animals were grouped in to their order of age and feed the plant for experimental animals and pellet for control group. Young rats were chosen because of their greater sensitivity to treatment. All the rats were observed individually at least once during the first $30 \mathrm{~min}$, periodically during the first $24 \mathrm{~h}$ with special attention given during the first $4 \mathrm{~h}$, and then daily for a total of 14 days. All the rats were observed at least twice daily with the purpose of recording any symptoms of ill-health or behavioral changes [15].

\section{Methods of data analysis Analytical equations}

In this study, the antioxidant activity, total phenolic content and total flavonoid content of $P$. quadrifida extracts were calculated and reported in terms of ascorbic acid (AA), gallic acid (GA), and querecetin (QT) equivalent per gram of extract. The equation stated below used for calculation from $\mathrm{Y}=\mathrm{BR}+\mathrm{C}$ linear equation.

$$
\mathrm{W}\left(\frac{m g}{g \text { of extract }}\right)=\frac{R(m g / m L)(\text { volume of extract }(m L))}{\text { weight of dry sample in gram }}
$$

where: $\mathrm{W}=\mathrm{GA}$, AAE, QT R $(\mathrm{mg} / \mathrm{mL})=\frac{Y-C}{B} / 1000$, $\mathrm{Y}=$ absorbance of the sample, $\mathrm{C}=\mathrm{y}$-intercept from calibration curve and $\mathrm{B}=$ slope from calibration curve.

The percentage of DPPH radical scavenging activities of Portulaca quadrifida extract was calculated with equation stated below:

$$
\text { DPPH radical scavenging }(\%) \text { activity }=\left[\frac{(A o-A 1)}{A o}\right] \times 100
$$

where: $A_{0}=$ absorbance of the control, $A_{1}=$ absorbance of the sample.

\section{Data analysis}

Total phenolic content, total flavonoid content, antioxidant activities in DPPH assay and zone of inhibition in antimicrobial activities were measured in triplicates to take the mean \pm SD value. The calibration curves and graphs were constructed by using Microsoft excel 2007. Statistical analysis was also undertaken by analysis of variance (one way ANOVA) with Least Significant Difference (LSD) to compare result between extracted plants by different solvents at the same concentrations using 
SPSS statistics version 20. Result was considered statistically significant at $\mathrm{P}$-value $<0.05$.

\section{Conclusion}

The extracts of the aerial parts of the Portulaca quadrifida were subjected to qualitative and quantitative analysis. The result of the study clearly indicated that nearly all investigated extracts showed antioxidant activity against DPPH radical scavenging activity. In antioxidant activity measurement, methanol extract, showed the highest percentage of DPPH radical scavenging activity. In addition to this, the study also showed that $P$. quadrifida extracts were found to contain measureable amount of total phenolic and flavonoid content which play major role in inhibiting oxidative stress in the body. Moreover, the results can also provide the effectiveness of $P$. quadrifida extracts for antimicrobial activity. All extracts of the plant also showed antimicrobial activity against different bacteria and fungi species. The acute toxicity result also revealed that the plant has no observable side effects. Generally the result of the study showed that the plant contains significant secondary metabolites and can be used as easily accessible source of food, natural antioxidant and antimicrobial activity.

\section{Authors' contributions}

ZYD was supervised the whole work as well as organized the manuscript as a whole and DAC did the experiment. All authors contributed to manuscript finalization. All authors read and approved the final manuscript.

\section{Author details}

${ }^{1}$ Department of Chemistry, College of Science, Bahir Dar University, P. O. Box 79, Bahir Dar, Ethiopia. ${ }^{2}$ Agricultural and Nutritional Research Laboratory, Ethiopian Institute of Agricultural Research (EIAR), P.O Box 2003, Addis Ababa, Ethiopia.

\section{Acknowledgements}

We would like to thank Bahir Dar University for financial support to do this research. DAC also thanks Agricultural and Nutritional Research Laboratory, Ethiopian Institute of Agricultural Research (EIAR) for study leave as well as financial support for his study.

\section{Competing interests}

The authors declare that they have no competing interests.

\section{Availability of data and materials}

The authors have the samples.

\section{Consent for publication}

All authors consent to the publication.

\section{Ethics approval and consent to participate}

All authors declare that they have ethics approval and consent to participate.

\section{Funding}

Waiver.

\section{Publisher's Note}

Springer Nature remains neutral with regard to jurisdictional claims in published maps and institutional affiliations.
Received: 18 October 2018 Accepted: 6 December 2018

Published online: 20 December 2018

\section{References}

1. Kirtikar KR, Basu DB (2001) Indian medicinal plants. Dehra Dun Uttaranchal India 2:333-335

2. Gidaya M, Asfaw Z, Woldu Z (2009) Medicinal plants of the Meinit ethnic group of Ethiopia: an ethno botanical study. J Ethnopharmacol 124:513-521

3. Vidya SJ (2016) Anti-diabetic activity of ethanolic extract of Portulaca quadrifida leaves. Int J Curr Res 8:29777-29779

4. Uddin MK, Juraimi AS, Ali ME, Ismail MR (2012) Evaluation of antioxidant properties and mineral composition of purslane (Portulaca oleracea L.) at different growth stages. Int J Mol Sci 13:10257-10267

5. Naidu LM, Babu NK (2009) Evaluation of in vitro antimicrobial activity of Portulaca quadrifida L. Int J Plant Sci. 4:494-497

6. Burkill HM (1997) The useful plants of West Trophical Africa. Families M-R. Royal Botanic Gardens, Kew. vol. 4, 2nd edn, p 969

7. Amin I, Norazaidah Y, Hainida KE (2006) Antioxidant activity and phenolic content of raw and blanched Amaranthus species. Food Chem. 94:47-52

8. Nguyen Q-V, Euni J-B (2011) Antioxidant activity of solvent extracts from Vietnamese medicinal plants. J Med Plants Res. 5:2798-2811

9. Chang C-C, Yang M-H, Wen H-M, Chern J-C (2002) Estimation of total flavonoid content in propolis by two complementary colorimetric methods. J Food Drug Anal. 10:178-182

10. Barku VYA, Opoku-Boahen Y, Owusu-Ansah E, Mensah EF (2013) Antioxidant activity and the estimation of total phenolic and flavonoid contents of the root extract of Amaranthus spinosus. Asian J Plant Sci Res. 3:69-74

11. Savitree M, Isara P, Nittaya SL, Worapan S (2004) Radical scavenging activity and total phenolic content of medicinal plants used in primary health care. J Pharm Sci 9:32-35

12. National Committee for Clinical Laboratory Standards (NCCLS) (2000) Methods for dilution: antimicrobial susceptibility test for bacteria that grow aerobically. 5 th edn. $p 20$

13. Cushnie TPT, Lamb AJ (2005) Antimicrobial activity of flavonoids. Int J Antimicrob Agents. 26:343-356

14. Arikan S, PaetznickV, Rex JH (2002) Comparative evaluation of disc diffusion with microdilution assay in susceptibility testing of Caspofungin against Aspergillus and Fusarium isolates. Antimicrob Agents Chemother. 46:3084-3087

15. OECD guidelines for the testing of chemicals (2011) Acute oral toxicityacute toxic class method 423

Ready to submit your research? Choose BMC and benefit from

- fast, convenient online submission

- thorough peer review by experienced researchers in your field

- rapid publication on acceptance

- support for research data, including large and complex data types

- gold Open Access which fosters wider collaboration and increased citations

- maximum visibility for your research: over $100 \mathrm{M}$ website views per year

At BMC, research is always in progress.

Learn more biomedcentral.com/submissions 